\title{
CORONAVIRUSES AND MULTIPLE SCLEROSIS
}

\author{
Ronald S. Murray, Guang-Yun Cai, Kristen Hoel, \\ Steven Johnson and Gary F. Cabirac \\ Rocky Mountain Multiple Sclerosis Center, Colorado \\ Neurological Institute, and Swedish Medical Center. \\ 701 E. Hampden Ave., Englewood, CO 80150; \\ Department of Biochemistry, Biophysics and Genetics \\ University of Colorado Health Sciences Center, Denver, Colorado
}

\section{INTRODUCTION}

Multiple sclerosis (MS) is a chronic inflammatory demyelinating disease of the human central nervous system (CNS) without known cause. A popular theory proposes that an exogenous stimulus initiates an immune response against self CNS proteins, possibly myelin structural protein(s). However, damage to the CNS as the result of an immune response to a chronic low grade CNS infection has never been ruled out. Therefore, demyelinating lesions in MS may represent the final direct or indirect immunopathological reaction to an infectious agent(s). Supporting this hypothesis are epidemiologic studies that strongly implicate an environmental factor in the development of MS (1). Particularly compelling is the MS epidemic in the Faroe Islands (2) and the recent study of offspring to immigrants to the United Kingdom from low incidence countries developing MS at rates similar to the indigenous English population (3).

Several common human RNA or DNA viruses have been implicated in the pathogenesis of MS but none have been definitively associated with the disease (4). Our laboratory and collaborators have been unsuccessful in detecting herpes simplex type I, cytomegalovirus, varicella zoster virus, Epstein Barr virus or borrelia burgdorferii (unpublished data), human T-cell lymphotropic virus $(5,6)$, or measles, mumps, and rubella viruses (7) in MS brain by either in situ hybridization, immunohistochemistry or the polymerase chain reaction.

Coronaviruses have been implicated in MS since the report of virus isolation from the brains of two MS patients and the electron microscopic observation of a coronavirus like particle in an MS brain perivascular immunocyte $(8,9)$. Coronaviruses are also known to cause demyelination $(10,11)$ and are capable of stimulating T-cell mediated autoimmune reactions in rodents $(12,13)$. Recently, we reported finding coronavirus RNA and antigen in active demyelinating plaques of MS autopsy brain thus further implicating coronaviruses in MS (14). This coronaviral RNA and antigen was detected primarily with cDNA probes and antibodies specific for MHV related coronaviruses. 
Although these results were surprising they are plausible since we then demonstrated that coronaviruses JHM and SD could infect the CNS and cause demyelination following intracerebral inoculation in several species of primates (15). Additonally, coronavirus 229E has recently been detected in MS brain by PCR technology (16).

Our current goals are to specifically identify the coronavirus(es) found in human brain and investigate how these coronaviruses interact with human brain cells and immune system. We now report the initial results and development of 1) PCR amplification of coronaviruses directly from human brain, 2) an MS brain derived cDNA library and screening for CV clones and 3) an in vitro human brain cell - coronavirus infection system.

\section{METHODS AND RESULTS}

\section{PCR Amplification of Coronaviruses from Human Brain}

Human brain samples were derived from MS and control autopsy samples used in prior in situ hybridization and immunohistochemical screens for the prescence of coronaviruses (15). All necessary precautions were taken to avoid contamination of RNA preparations with exogenous sources of RNA and DNA. Total RNA extracted from frozen human brain was reversed transcribed using the following reaction conditions. 1ug of RNA was mixed with 100pmoles of random hexamers (Boehringer Mannheim) in a total volume of $15 \mathrm{ul}$, heated at $65^{\circ} \mathrm{C}$ for $5 \mathrm{~min}$ then cooled at room temperature. CVP1 5' T T GAGGCTCTGGAAGGTCTGC and CVP2 5'CTGCAAGAATGGGGAACTGTGG was the inital set of primers. The CVP1/P2 product is $374 \mathrm{bp}$ for MHV and $441 \mathrm{bp}$ for OC43. 5ul of $\mathrm{P} 1 / \mathrm{P} 2$ reaction is removed, mixed into $100 \mathrm{ul} \mathrm{H}_{2} \mathrm{O}$ and then $5 \mathrm{ul}$ of this, i.e. approx. $0.05 \mathrm{ul}$ of original rxn, is used in second round PCR with P3/P4 primers. The nested set reaction conditions are as follows:10ul of a enzyme/buffer/dNTP mix was added to the RNA/primer tube and the reaction was incubated at $43^{\circ} \mathrm{C}$ for $1 \mathrm{hr}$. The final reverse transcriptase reaction conditions were $40 \mathrm{ug} / \mathrm{ml}$ RNA, $4 \mathrm{uM}$ random hexamers, $50 \mathrm{mM}$ Tris, $\mathrm{pH} 8.3,100 \mathrm{mM}$ $\mathrm{KCl}, 10 \mathrm{mM} \mathrm{MgCl}$, 4mM DTT, 1 unit/ul RNasin (Promega), $1 \mathrm{mM}$ dNTPs, and 5 units of AMV reverse transcriptase (LifeSciences, Inc.). Reactions were heated at $97^{\circ} \mathrm{C}$ for 5 min then stored at $-20^{\circ} \mathrm{C}$.PCR reaction conditions were as follows. Tubes containing $85 \mathrm{ul}$ of buffer, primers, enzyme and approximately $100 \mathrm{ul}$ of mineral oil were heated to $80^{\circ} \mathrm{C}$ in the Perkin Elmer Thermocycler. 5ul of the cDNA from the reaction described above was mixed with $10 \mathrm{ul}$ of $2 \mathrm{mM}$ dNTPs in a separate tube and this was then added through the oil into the PCR reaction tube. The final reaction conditions were: $10 \mathrm{mM}$ Tris, $\mathrm{pH} 8.8,50 \mathrm{mM} \mathrm{KCl}, 1.5 \mathrm{mM} \mathrm{MgCl}_{2}, 0.2 \mathrm{mM}$ dNTP, $0.1 \%$ Triton X-100, 0.5uM of each primer, and 5 units of Taq polymerase (Promega). The temperature profile for the reactions was as follows: $95^{\circ} \mathrm{C} / 1 \mathrm{~min}, 58^{\circ} \mathrm{C} / 1.5 \mathrm{~min}, 72^{\circ} \mathrm{C} / 3 \mathrm{~min}$ for 3 cycles then $95^{\circ} \mathrm{C} / 1 \mathrm{~min}, 62^{\circ} \mathrm{C} / 1 \mathrm{~min}, 72^{\circ} \mathrm{C} / 2 \mathrm{~min}$ for 36 cycles followed by incubation at $72^{\circ} \mathrm{C}$ for $7 \mathrm{~min}$. The PCR primers, CVP3 and CVP4, used for these reactions were designed based on the published sequences of the nucleocapsid genes of MHV A59 and HCV OC43 (2,22). Viral cDNA amplified with CVP3, 5'IIAAATTGCTIITCTTGTTCTGGC (I=inosine), and CVP4, 5' CCAAAATTCTGATTAGGGCCTCTC, produce a $186 \mathrm{bp}$ PCR product. These primers amplify a region extending from nucleotide 858 to 1043 or 784 to 969 for MHV A59 or HCV OC43, respectively. The PCR reaction products were analyzed by gel electrophoresis and Southern-blot hybridization. The ${ }^{32} \mathrm{P}$ labeled probe used for hybridization,CVPP has the sequence 5'AAGCAIAITGCCAAAIAAGTCAGICAGAAAATTTT; this hybridizes specifically to the 186bp CV PCR product. 
Table 1. CV PCR amplification from Ms brain.

\begin{tabular}{|c|c|c|c|}
\hline Sample & Diagnosis & Brain Region & PCR Product \\
\hline TO-1 & MS & Cerebrum & Positive \\
\hline TO-2 & MS & Brain stem & Negative \\
\hline ZO & MS & Cerebrum & Positive \\
\hline $\mathrm{ZOH}$ & MS & Cerebrum & Negative \\
\hline HO & MS & Cerebrum & Negative \\
\hline $\mathrm{KN}-1$ & MS & Cerebrum & Negative \\
\hline $\mathrm{KN}-2$ & MS & Spinal Cord & Negative \\
\hline ME & MS & Cerebrum & Positive \\
\hline sz & MS & Cerebrum & Negative \\
\hline SY & MS & Cerebrum & Negative \\
\hline RO & MS & Cerebellum & Negative \\
\hline TR & MS & Spinal Cord & Negative \\
\hline SC & MS & Cerebrum & Negative \\
\hline $\begin{array}{l}\text { DI-cDNA } \\
\text { library }\end{array}$ & MS & Cerebrum & Positive \\
\hline $\mathrm{HA}$ & Cardiac & Cerebellum & Negative \\
\hline OR & Cardiac & Cerebrum & Positive \\
\hline MU & Cardiac & Cerebrum & Negative \\
\hline LA & Sepsis & Cerebrum & Negative \\
\hline MC & Cardiac & Cerebrum & Negative \\
\hline
\end{tabular}

Table 1 shows our intial PCR results for 12 MS patients with 4 having amplifiable coronavirus product. MS sample DI was amplified from a cDNA library made from mRNA from this patients white matter. Sequencing of this amplified product demonstrated high homology with the puplished sequence of JHM. One of control brain samples had amplifiable product. To date these products have not been sequenced.

\section{Coronavirus Infection of Human Brain Cells}

Primary or continuous human and murine cell cultures were infected with coronavirus JHM, SD or sham inoculums. Origin and methods of growing coronaviruses JHM, JHM OMp1 and SD have been described $(11,15)$. The human astrocyte cell line STTG-1 was obtained from the ATCC and maintained under standard cell culture conditions. Human primary brain cultures were derived from the resected epileptic cortex of two patients ( $\mathrm{F}$ and $\mathrm{V}$ ). Cells were grown in DMEM-10\%FCS medium. DBT and $17 \mathrm{Cl} 1$ cells growth and maintenance have been described $(8,11)$. Cultures were observed for CPE and infectious virus production. Additionally, all cultures were analyzed for the prescence of viral products by immunohistochemistry $(14,15)$, western and northern blots and PCR amplification from isolated cell RNA as described (15). To inhibit infection, viral inoculums were pretreated with a polyclonal anti-coronavirus antibody (gift from J. Leibowitz).

Table 2 shows the results of infection with JHM of human and murine cell lines. Primary brain cultures and the human astroytoma cell line STTG could be infected. The infection was of a very low grade and complete CPE would not develop for 5 to 6 days post adsorption. In contrast, murine DBT cells and $17 \mathrm{Cl}-1$ cells could be productively infected by JHM. Similar results were seen with CV SD and the primate isolate JHM OMp1. In general only low levels of virus were detectable in human cells suggesting that these cells were prone to being persistently infected. However the exact mechanisms will require further investigation. 
Table 2. Infection of cell Lines with Coronavirus.

$\begin{array}{lrrrrrr}\text { System } & \text { CPE } & \text { Virus } & \text { PCR } & \text { Northern } & \text { IF } & \text { Western } \\ \text { 17Cl-1 } & - & - & - & - & - & - \\ \text { I7Cl + JHM } & + & + & + & + & + & + \\ \text { V Primary Brain } & - & - & - & - & - & - \\ \text { V + JHM } & + & \text { ND } & + & - & + & - \\ \text { F Primary Brain } & - & - & - & - & - & - \\ \text { F + JHM } & + & \text { ND } & + & - & + & - \\ \text { STTG } & - & - & - & - & - & - \\ \text { STTG + JHM } & + & + & + & - & + & - \\ \text { DBT } & - & - & - & - & - & - \\ \text { DBT + JHM } & + & + & + & + & + & + \\ \end{array}$

a. Pretreatment with antibody prevents CPE in all cells

b. Similar results with CV SD and JHM-OMp1

\section{DISCUSSION}

Despite the intensive investigations of neurotropic coronaviruses in rodents, human neurologic disease resulting from coronavirus infection has not been proven. However, accumulating data, in addition to the results presented here, suggest that coronaviruses may infect human CNS tissue and that these viruses may differ from the prototypical upper respiratory human coronaviruses. In one case, a coronavirus (Tettnang virus) was isolated from the cerebrospinal fluid of a young girl with viral meningitis following an upper respiratory infection (17). This human coronavirus isolate was suspected by the authors to be more closely related to murine coronavirus than to human coronavirus. Recently, Parkinsons disease patients were reported to have high cerebrospinal fluid antibody titers specific to the murine coronaviruses MHV A59 and MHV JHM when compared to patients with other neurologic disease or non-disease controls (18). Burks et al reported the isolation of two coronavirus (SD \& SK) from MS autopsy brain tissue after passage through suckling mice or murine cell culture (8). Although these isolates have serologic cross reactivity to murine coronavirus and HCV OC43 (19) others have demonstrated that these putative MS coronavirus isolates are antigenically and genetically more closely related to murine coronavirus than to the human coronavirus $(19,20)$; our results show a $97 \%$ sequence identity in the 3' end of the genome between coronavirus SD and MHV JHM (unpublished data). Additionally, we have demonstrated murine-like coronaviruses directly in demyelinating plaques of autopsy MS brain. We have also reported the CNS infection of primates (14). Taken together these data suggest that coronaviruses can infect the human CNS and may play a role in multiple sclerosis pathogenesis.

The results presented in this paper demonstrate the value of PCR as a sensitive method to screen human brain and cell lines for the prescence of minute amounts of coronavirus RNA. Additionally this represents a third method of identifying "murine" related CV in multiple sclerosis brain. Coronavirus specific PCR products were amplified from one MS cDNA library and sequenced. The sequence of this product had a $94 \%$ identity to JHM. This cDNA library will now allow us to "rescue" other 
regions of this coronavirus. Hopefully we will glean data on the possibility of a human-murine recombinant virus versus a mutant murine coronavirus. Our in vitro results show that JHM is able to infect at low levels human STTG-1 cells and primary human brain culture cells. The infection takes several days to develop and can be inhibited by pretreatment of virus with neutralizing antibody. Infection of STTG-1 cells will be important in studying the human cellular immune response to these viruses. This will be possible since these cells are HLA DR2 and are known to present foreign antigens to T-cells.

The data presented here do not establish coronaviruses as an etiological agent for MS, but they do indicate that coronaviruses are present in the human CNS and are preferentially detected in MS tissue. However the stage is set for identifying the antigenic structure of these coronaviruses and to begin investigations of the cellular immunity to these antigens in HLA DR2 MS patients.

\section{Acknowledgements}

This work was supported by grants from the Swedish Medical Foundation and Fausel Foundation. The Rocky Mountain MS Center Tissue bank is supported by grant \#RG2108-B-5 from the National Multiple Sclerosis Society.

\section{REFERENCES}

1. J.F.Kurtzke, Neurology. 30:61(1980).

2. J.F.Kurtzke, K.Hyllested, Ann Neurol. 5:6(1979).

3. M.Elian, S.Nightingale, G.Dean, J Neurol Neurosurg Psychiatry. 53:906(1990).

4. J.Booss, J.H.Kim,in: "Handbook of Multiple Sclerosis," S.D.Cook, ed., Marcel Dekker, Inc.,New York, New York(1990).

5. $\quad$ G.F.Cabirac, D.Ries, R.S.Murray, Ann Neurol. 29:343(1991).

6. G.D.Ehrlich, J.B.Glaser, V.Bryz-Gornia,et al.Neurology.41:335(1991).

7. M.S.Godec, D.M.Asher, R.S.Murray, et al.Ann Neurol. In Press (1992).

8. J.S.Burks, B.L.DeVald, L.D.Jankovsky, J.G.Gerdes, Science. 209:933(1980).

9. R.Tanaka, Y.Iwasaki, H.Koprowski, J Neurol Sci. 28:121(1976).

10. L.P.Weiner, Arch Neurol 28:298(1973).

11. P.M.Mendelman, L.D.Jankovsky, R.S.Murray, et al, Arch Neurol 40:493(1983).

12. S.Kyuwa, K.Yamaguchi, Y.Toyoda, K.Fujiwara, Virol 65:1789(1991).

13. R.Watanabe, H.Wege, V.ter Meulen, Nature 305:150(1983).

14. R.S.Murray, B.Brown, D.A.Brian, G.F.Cabirac, Ann Neurol 31:525(1992).

15. R.S.Murray, G-Y Cai, K.Hoel, et al, Virology. 188:274(1992).

16. J.N.Stewart, S.Mounir, P.J.Talbot, Virology. In Press, (1992).

17. D.Malkova, J.Holubova, J.M.Kolman, et al. Acta Virol(Prague) (Engl Ed). 24(5):363(1980).

18. E.Fazzini, J.O.Fleming, S.Fahn, Neurol(Suppl 1).40:169(1990).

19. J.C.Gerdes, I.Klein, B.L.DeVald, J.S.Burks, J Virol.38:231(1981).

20. J.O.Fleming, F.A.K.Zaatari, W.Gilmore, et al, Arch Neurol. 45:629(1988).

21. S.R.Weiss, Virology 126:669(1983). 